\title{
Post Transcriptional Regulation of Gene Expression
}

\author{
Nida Tabassum Khan \\ Department of Biotechnology, Faculty of Life Sciences and Informatics, Balochistan University of Information \\ Technology Engineering and Management Sciences,(BUITEMS), Quetta, Pakistan
}

*Corresponding Author: Nida Tabassum Khan, Department of Biotechnology, Faculty of Life Sciences and Informatics, Balochistan University of Information Technology Engineering and Management Sciences,(BUITEMS), Quetta, Pakistan

\begin{abstract}
Post transcriptional regulation by means of RNA editing is a very powerful gene regulation mechanism which aimed to control gene expression at translational level. However this regulation mechanism could result in genetic mutations causing gene products to function abnormally or rendered them completely non-functional depending on the length of the mutated protein
\end{abstract}

Keywords: mRNA; Familial hypobetalipoproteinemia; RNA editing

\section{INTRODUCTION}

RNA editing is a post transcriptional modification mechanism of premature mRNA. Non-coding regions such as in trons are removed from the premature mRNA so the resulting RNA sequence only contains the coding sequences of a gene. Evidences were gathered to show that RNA editing contributes in mRNA stability and this mechanism is quiet common in unicellular and multi cellular eukaryotic organisms such as in mammals, plants, nematodes, viruses, fungi, protozoa, marsupials, fruit fly, slime molds etc [1]. Besides contributing in mRNA stability, RNA editing is responsible for producing novel or mutated proteins. This post transcriptional regulation of gene expression could result in phenotypic effects that could be beneficial or deleterious [2].

\section{APOLIPOPROTEIN B MRNA EDITING}

Apolipoprotein B (APOB) gene is responsible for coding two apolipoprotein B proteins. A 48 amino acid short B-48 and a 100 amino acid long B-100apolipoprotein. These lipoprotein functions in transport of cholesterol and lipids in the blood. Chylomicrons is formed by B-48 apolipoprotein in the intestine which transport cholesterol and fats into the blood circulation. Chylomicrons are also required for the absorption of fat-soluble vitamins A and E.B-100 apolipoprotein on the other hand is produced in the liver and is a constituent of VLDLs (very low-density lipoproteins), IDLs (intermediate-density lipoproteins) and LDLs (low-density lipoproteins) which also act as cholesterol transporters [4]. B-100 lipoprotein permits cholesterol or fats molecules to adhere to explicit receptors present on the surface of the liver cells which transfer low-density lipoproteins into the cell to release cholesterol which is then utilized by the cell. Post transcriptional editing of apolipoprotein B mRNA involves deamination of cytidine to uridine at nucleotide position 6666. As a result glutamine codon (CAA)is altered to a stop codon (UAA) that terminates translation producing two lipoproteins which differs in their amino acids counts [5] (Figure 1).

\section{Mutations in APOLIPOPROTEIN B GENE}

Familial hypobetalipoproteinemia is caused by $>90$ mutations occurring in Apolipoprotein B (APOB) gene. It is a type of genetic disorder in which the body fails to absorb and transport cholesterol [6]. Mutations in apolipoprotein B gene produces either a B-48 lipoproteins that is shorter than apolipoprotein B-100.Severity of the disorder depends on the length of the polypeptide. Even in these scenarios, normal length B-48 lipoprotein is still produced in the intestine which forms chylomicron 
but the mutated B-100 made in the hepatic cells is less likely to be a part of lipoproteins. In extreme cases mutation produces a protein that is even shorter than B-48 and B-100apolipoprotein. As a result no normal length apolipoprotein B protein is produced $[7,8]$. This extremely short protein is unable to form lipoproteins in the intestine or even in the liver. The resultant symptoms of the disorder are extremely severe due to the non-functionality of the mutated protein in the transportation of dietary fats and cholesterol. As a result affecting absorbtion of fats and fat-soluble vitamins from the diet leading to familial hypobetalipoproteinemia [9] (Figure 2).

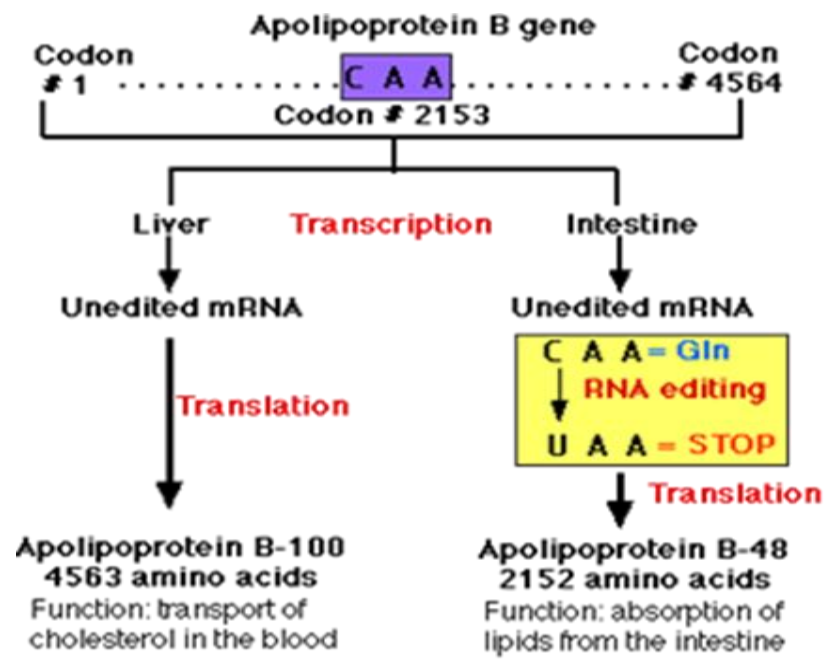

Fig1. Editing of apolipoprotein B mRNA [5]

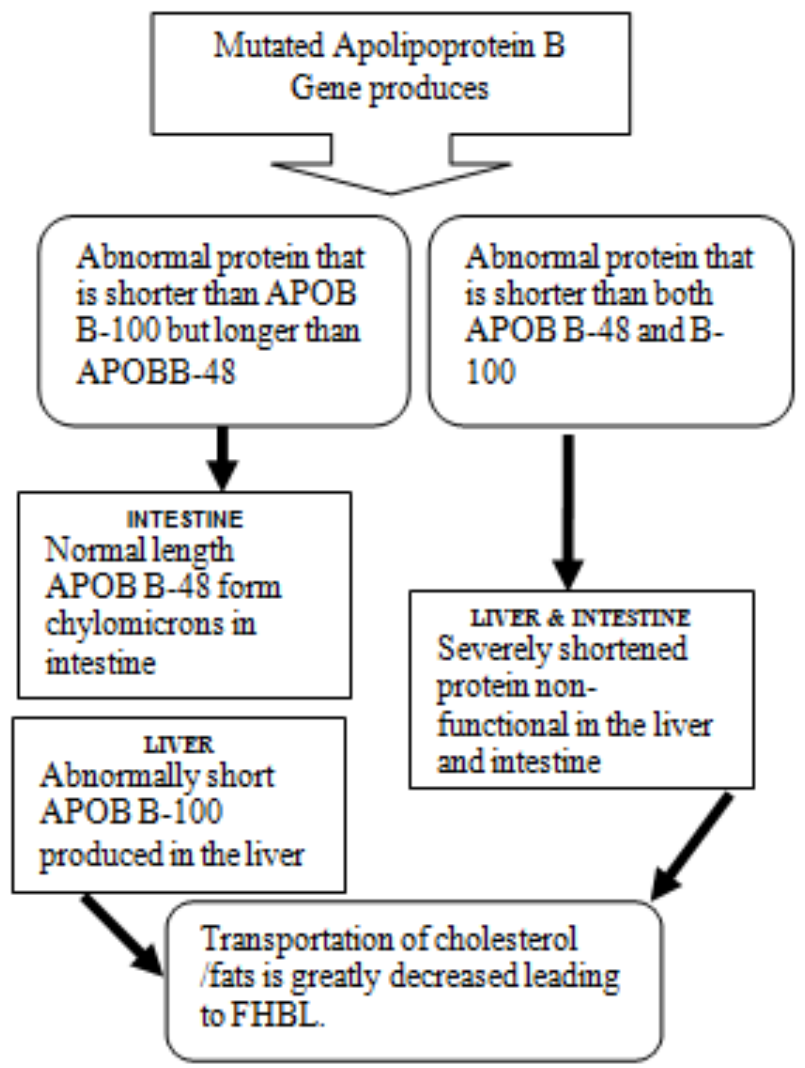

Fig2. Mutations in the Apolipoprotein B Gene

Familial defective apolipoprotein B-100 is produce by a minimum of five mutations in the APOB gene .Abnormal level of cholesterol is detected in the blood of the affected ones leading to an elevated risk of developing heart diseases. The transformed protein prevents adhesion of lipoproteins to their respectivereceptors. As a result affecting normal cholesterol levels in the blood. Abnormalcholesterol present in the blood is deposited in different tissues such as skin, tendons, and walls of coronary arteries causing heartstrokes $[10,11,12]$. 


\section{CONCLuSion}

Thus an effective yet a major cause of genetic disorders such as familial hypobetalipoproteinemia and inherited hypercholesterolemia.

\section{REFERENCES}

[1] Gerber, A. P., \& Keller, W. (2001). RNA editing by base deamination: more enzymes, more targets, new mysteries. Trends in biochemical sciences, 26(6), 376-384.

[2] Brennicke, A., Marchfelder, A., \& Binder, S. (1999). RNA editing. FEMS microbiology reviews, 23(3), 297-316.

[3] Blackhart, B. D., Ludwig, E. M., Pierotti, V. R., Caiati, L., Onasch, M. A., Wallis, S. C., ... \& Chu, M. L. (1986). Structure of the human apolipoprotein B gene. Journal of Biological Chemistry, 261(33), 1536415367.

[4] Morrison, J. R., Pászty, C., Stevens, M. E., Hughes, S. D., Forte, T., Scott, J., \& Rubin, E. M. (1996). Apolipoprotein B RNA editing enzyme-deficient mice are viable despite alterations in lipoprotein metabolism. Proceedings of the National Academy of Sciences, 93(14), 7154-7159.

[5] Young, S. G., Hubl, S. T., Smith, R. S., Snyder, S. M., \& Terdiman, J. F. (1990). Familial hypobetalipoproteinemia caused by a mutation in the apolipoprotein B gene that results in a truncated species of apolipoprotein B (B-31). A unique mutation that helps to define the portion of the apolipoprotein B molecule required for the formation of buoyant, triglyceride-rich lipoproteins. Journal of Clinical Investigation, 85(3), 933.

[6] Farese, R. V., Linton, M. F., \& Young, S. G. (1992). Apolipoprotein B gene mutations affecting cholesterol levels. Journal of internal medicine, 231(6), 643-652.

[7] Tybjærg-Hansen, A., Steffensen, R., Meinertz, H., Schnohr, P., \& Nordestgaard, B. G. (1998). Association of mutations in the apolipoprotein B gene with hypercholesterolemia and the risk of ischemic heart disease. New England Journal of Medicine, 338(22), 1577-1584.

[8] Hooper AJ, van Bockxmeer FM, Burnett JR. Monogenic hypocholesterolaemic lipid disorders and apolipoprotein B metabolism. Crit Rev Clin Lab Sci. 2005; 42(5-6):515-45. Review.

[9] Schonfeld G, Lin X, Yue P. Familial hypobetalipoproteinemia: genetics and metabolism. Cell Mol Life Sci. 2005 Jun;62(12):1372-8. Review.

[10] Vrablík M, Ceska R, Horínek A. Major apolipoprotein B-100 mutations in lipoprotein metabolism and atherosclerosis. Physiol Res. 2001; 50(4):337-43. Review.

[11] Tarugi P, Averna M, Di Leo E, Cefalù AB, Noto D, Magnolo L, Cattin L, Bertolini S, Calandra S. Molecular diagnosis of hypobetalipoproteinemia: an ENID review. Atherosclerosis. 2007 Dec;195(2):e1927. Epub 2007 Jun 14. Review

[12] Vrablík M, Ceska R, Horínek A. Major apolipoprotein B-100 mutations in lipoprotein metabolism and atherosclerosis. Physiol Res. 2001; 50(4):337-43. Review.

Citation: Nida Tabassum Khan, "Post Transcriptional Regulation of Gene Expression", International Journal of Research Studies in Biosciences (IJRSB) , vol. 5, no. 9, p. 1-3, 2017. http://dx.doi.org/10.20431/23490365.0509001

Copyright: () 2017 Authors. This is an open-access article distributed under the terms of the Creative Commons Attribution License, which permits unrestricted use, distribution, and reproduction in any medium, provided the original author and source are credited. 